\title{
ВПЛИВ ІНСПІРАТОРНИХ М'ЯЗОВИХ ТРЕНУВАНЬ НА ПОКАЗНИКИ ТЕРАПЕВТИЧНОГО АЛЬЯНСУ У РАМКАХ ПРОГРАМИ ФІЗИЧНОЇ ТЕРАПІЇ КАРДІОХІРУРГІЧНИХ ПАЦІЕНТІВ
}

\section{Вітомський Володимир}

Викладач Національний університет фізичного виховання і спорту України, Україна

\begin{abstract}
Анотація: мета оцінити вплив включення тренувань інспіраторних м'язів на формування терапевтичного альянсу у рамках стаціонарної програми фізичної терапії після кардіохірургічних втручань. У опитуванні взяли участь 88 пацієнтів, котрим проводилося кардіохірургічне втручання з стернотомією та штучним кровообігом. Пачієнтів випадковим чином розподілили у співвідношенні 1:1 на контрольну групу (КГ, $n=44)$ та групу тренувань інспіраторних м'язів (IMT, $n$ = 44). 3 усіма пацієнтами перед операџією проводилася коротка консультація фізичного терапевта щзодо иілей та змісту програми фізичної терапії, алгоритму активізації після операції. Післяопераційний протокол фізичної терапії передбачав ранню мобілізацію, лікувальну гімнастику. Після операщії респіраторна фізична терапія у КГ обмежувалася кашлем, а у групі IMT додатково використовувався дихальний тренажер Respironics Threshold IMT i відповідно навчання пацієнтів щуодо особливостей його використання. Таким чином, для пацієнтів групи IMT було характерним додаткове формування та досягнення специфічних иілей та завдань при роботі з дихальними тренажерами, додаткова співпраџя пацієнта з фізичним терапевтом, котра реалізовувалася у формі пояснень особливостей $і$ алгоритму роботи, контролю практичної реалізачії дихальних вправ, контролю формування правильної навички, своєчасної корекції помилок для покращення техніки, мотивування та підвищення старанності пацієнта при виконанні дихальних вправ з тренажерами. 3 метою оцінки рівня формування терапевтичного альянсу застосовувався опитувальник Очінка робочого альянсу. Порівняння результатів груп за пунктами опитувальника не встановило достовірних відмінностей між вибірками у жодному пункті анкети. Порівняння результатів доменів також не встановило достовірних відмінностей між групами пацієнтів. Результати домену «иіль» склали $18(15 ; 19,75)$ балів у КГ та $19(15,25 ; 20)$ балів у IMT (p=0,259). У домені «завдання» статистичні показники КГ склали 17 (14; 18) балів, а у IMT 16,5 (14; 19) балів (p=0,680). Порівняння показників домену «взаємовідносини» не встановило преваг жодної з вибірок: КГ 16 $(13,25 ; 18)$ балів, а IMT - $17(13,25 ; 18)$ балів $(p=0,681)$. Загальний показник у групах також не відрізнявся у КГ та IMT: 51 (43,25; 54,75) бал проти 52 (42,25; 56) бала $(p=0,437)$. Додаткове визначення, узгодження та прочес досягнення специфічних для роботи з дихальними тренажерами цілей та завдань не покращчли результати терапевтичного альянсу незважаючи на те, щзо вправи з дихальними тренажерами були додатковою співпрацею між фізичними терапевтами та пацієнтами у групі тренувань інспіраторних м'язів.
\end{abstract}

Ключові слова: кардіореабілітація, робочий союз, терапевтичні вправи, фізична терапія, дихальні вправи.

Вступ. Актуальною та важливою частиною систем охорони здоров'я $\epsilon$ фізична терапія (ФТ) пацієнтів кардіологічного та кардіохірургічного профілю (Vitomskiy et al., 2018; Balazh et al., 2020). Водночас становлення біопсихологічного підходу у ФТ та інших напрямках охорони здоров'я $\epsilon$ актуальними напрямками наукових досліджень (Kinney et al., 2020; Fedorenko et al., 2020). Однією зі сторін біопсихологічної моделі є терапевтич-

Cite as: The influence of inspiratory muscle training on indicators of therapeutic alliance during physical therapy program of cardiosurgery patients 
ний альянс, котрий досліджується й у галузі ФT (Hall et al., 2010; Taccolini Manzoni, et al., 2018; Kinney et al., 2020). Вивчається вплив терапевтичного альянсу на результати ФТ та рівень задоволеності пацієнта (Ferreira et al., 2013; Taccolini Manzoni et al., 2018; Lawford et al., 2020). Проте, досліджень не вистачає в літературі з реабілітації та ФТ, а також наявні суперечливі результати (Babatunde et al., 2017). Терапевтичний альянс включає такі характеристики, як колаборативний характер, узгодженість мети та завдань, афективний зв'язок (Martin et al., 2000), емпатія (Mercer et al., 2004) та довіра (Hall et al., 2002).

У сфері кардіохірургії пацієнти планово отримують ФТ, котра спрямована на ранню мобілізацію та відновлення функціональних можливостей. У таких умовах вивчення формування терапевтичного альянсу між пацієнтом та фізичним терапевтом є дуже цікавим, оскільки передопераційне перебування у кардіохірургічному відділенні може супроводжуватися відчуттями занепокоєння, а післяопераційне тимчасовим зниженням незалежності у самообслуговуванні та функціональних можливостей. Потребує вивчення вплив додаткових чи варіативних інтервенцій фізичних терапевтів на покращення рівня терапевтичного альянсу. Зокрема використання респіраторної ФТ вимагає проведення навчання щодо використання дихального тренажера, формування та досягнення додаткових цілей, завдань, що відбувається шляхом додаткової співпраці фізичного терапевта та пацієнта.

Мета: оцінити вплив включення тренувань інспіраторних м'язів на формування терапевтичного альянсу у рамках стаціонарної програми ФТ після кардіохірургічних втручань.

Матеріали та методи. У опитуванні взяли участь 88 пацієнтів (старше 18 років, без когнітивних порушень). Критерії виключення: нестабільна стенокардія на момент відбору або під час програми, серцева недостатність III, складна шлуночкова та неконтрольована аритмія, неконтрольований високий кров'яний тиск, порушення мозкового кровообігу, штучна вентиляція легень більше 24 годин. Дизайн дослідження - рандомізоване контрольоване дослідження. Усі учасники погоди- лись взяти участь у дослідженні і самостійно заповнювали опитувальники, після короткого інструктажу. При заповненні анкет допомога консультантів, котра була можливою за потреби, не використовувалася. Протокол дослідження був затверджений місцевим комітетом 3 медичної етики ДУ «Науково-практичний медичний центр дитячої кардіології та кардіохірургії МОЗ України» (протокол №1 від 21.01.2020). Пацієнтів методом конвертів розподілили у співвідношенні 1:1 на контрольну групу (КГ; $\mathrm{n}=44)$ та групу тренувань інспіраторних м'язів (IMT; $\mathrm{n}=44$ ).

Для оцінки формування терапевтичного альянсу використовувалася анкета Working Alliance Inventory (WAI, Оцінка робочого альянсу). Опитувальник створений 3 метою оцінювання елементів співпраці для усіх форм відносин, котрі пов'язані з допомогою (Horvath, 1994; Munder et al., 2010). Застосовувалася форма опитувальника SF Hatcher Client (12 питань). Питання анкети розділені на групи/домени: «ціль»; «завдання»; «взаємовідносини». Для оцінки застосовується 5-бальна шкала Лікерта, яка варіюється від 1 бала («рідко») до 5 («завжди»). Максимальна оцінка у домені 20 балів; для загального балу -60 балів. Мінімальні значення- 4 та 12 балів відповідно. Опитувальник заповнювався пацієнтом на сьомий післяопераційний день (ПОД).

Втручання. 3 усіма пацієнтами перед хірургічним втручанням проводилася коротка консультація фізичним терапевтом про цілі і зміст програми ФТ, особливостей активізації після хірургічного втручання. Післяопераційна програма ФТ передбачала наступний алгоритм ранньої активізації: виконання сидіння на ліжку у 1 ПОД (ноги опущені вниз); вставання 3 ліжка за участю і контролем фізичного терапевта (забезпечувалася можливість допомагати руками завдяки опорі на медичний ходунок) та ходьба на місці у 1 ПОД; у 2 ПОД- виконання ходьби на місці, ходьби палатою; у 3 ПОД-виконання ходьби коридором; у 4-5 ПОД - виконання ходьби сходами. Разом з тим, пацієнти разом 3 фізичними терапевтам виконували терапевтичні вправи у формі лукувальної гімнастики. Заняття лікувальною гімнастикою проводилися у 1 та 2 ПОД 2 рази на день, у 
3 ПОД 1-2 рази, з 4 ПОД 1 раз. При необхідності (необхідність мотивації чи контролю, стан пацієнта) кількість і тривалість занять лікувальною гімнастикою могла збільшуватися відповідно до рішення фізичного терапевта. Для самостійного виконання пацієнти отримували інформацію і завдання щодо невеликого комплексу терапевтичних вправ для самостійного виконання і лікувальної ходьби.

Групи різнились у респіраторній ФТ. У КГ респіраторна ФТ обмежувалася кашлем. Пацієнти IMT додатково виконували дихальні вправи за допомогою дихального тренажеpa Respironics Threshold IMT (три сети по 10 сильних, повних вдихів через дихальний тренажер на заняттях лікувальною гімнастикою, а також отримували рекомендації виконувати 3 сети 310 дихальних циклів щогодини). Пацієнтам IMT пропонувалося починати виконувати робити вдих через тренажер після повного видиху. Тренування з дихальним тренажером починалося 31 ПОД. Усі учасники КГ та IMT реєстрували свої щоденні дихальні тренування у щоденники для покращення систематичності.

Таким чином, для пацієнтів групи IMT було характерним додаткове формування та досягнення специфічних цілей та завдань при роботі 3 дихальними тренажерами, додаткова співпраця пацієнта 3 фізичним терапевтом, котра реалізовувалася у формі пояснень особливостей і алгоритму роботи, контролю практичної реалізації дихальних вправ, контролю формування правильної навички, своєчасної корекції помилок для покращення техніки, мотивуван- ня та підвищення старанності пацієнта при виконанні дихальних вправ з тренажерами.

Статистичний аналіз. Результати опрацьовувалися методами математичної статистики. Була використана прикладна програмама IBM SPSS Statistics 21. Для показників, котрі мали розподіл відповідний закону нормального розподілу, розраховувалися середнє арифметичне значення і середньоквадратичне відхилення $( \pm \mathrm{S})$. Для результатів, котрі розподілялися не відповідно до закону нормального розподілу, розраховувалися медіана, верхній та нижній квартилі $(\mathrm{Me}(25 \% ; 75 \%)) .3$ метою оцінки значущості різниці використовувався t-критерій Стьюдента (незалежні групи; при нормальному розподілі результатів), а для інших показників застосовували Mann-Whitney U-test. Однорідність груп за статтю, ступенем гіпертонічної хвороби та функціональним класом NYHA перевірялася за критерієм $\chi^{2}$.

Результати. До КГ ввійшло 30 чоловіків та 14 жінок, а до групи IMT 28 чоловіків та 16 жінок. Статистичний аналіз не встановив достовірної відмінності між групами за статтю пацієнтів $(\mathrm{p}=0,653)$. Значимих відмінностей у віці, масі та довжині тіла, тривалості операції не виявлено (табл. 1). Ступінь гіпертонічної хвороби та функціональний клас NYHA статистично не відрізнявся у групах, а показники Ме $(25 \% ; 75 \%)$ становили $2(0 ; 3)$ у КГ та $2(2 ; 3)$ у IMT $(\mathrm{p}=0,371), 2(2 ; 3)$ у КГ та $2,5(2 ; 3)$ y IMT $(\mathrm{p}=0,793)$.

Порівняння результатів груп за пунктами опитувальника не встановило достовірних відмінностей між вибірками у жодному

Таблиця 1. Загальні характеристики вибірок

\begin{tabular}{|c|c|c|c|}
\hline Показники & КГ $(n=44)$ & IMT $(n=44)$ & $\mathbf{p}$ \\
\hline Вік, роки & $61(52,25 ; 68)$ & $63,5(57 ; 69)$ & $0,270^{*}$ \\
\hline Маса тіла, кг & $82,78 \pm 15,12$ & $79,14 \pm 13,17$ & $0,231^{\#}$ \\
\hline Довжина тіла, см & $169,29 \pm 9,00$ & $167,61 \pm 9,60$ & $0,399^{\#}$ \\
\hline Індекс маси тіла, кг/м² & $28,86 \pm 4,82$ & $28,21 \pm 4,40$ & $0,508^{\#}$ \\
\hline Фракція викиду лівого шлуночка, \% & $53,32 \pm 7,59$ & $50,43 \pm 9,93$ & $0,129^{\#}$ \\
\hline Тривалість операції, хв. & $382,09 \pm 79,93$ & $392,27 \pm 96,72$ & $0,592^{\#}$ \\
\hline Тривалість штучного кровообігу, хв. & $178,27 \pm 57,15$ & $199,68 \pm 66,82$ & $0,110^{\#}$ \\
\hline Тривалість штучної вентиляції легень, год & $7(6 ; 10,5)$ & $8(6 ; 9)$ & $0,631^{*}$ \\
\hline
\end{tabular}

Примітка: " - t-критерій Стьюдента; * - U-критерій Манна-Уітні. 
Таблиця 2. Показники терапевтичного альянсу у групах пацієнтів, бали

\begin{tabular}{|r|l|c|c|c|}
\hline \multicolumn{2}{|c|}{ Пункти опитувальника } & КГ (n=44) & $\begin{array}{c}\text { IMT } \\
(\mathbf{n = 4 4 )}\end{array}$ & p \\
\hline 1. & $\begin{array}{l}\text { У результаті цих сесій я більш чітко розумію, як я можу } \\
\text { змінитися }\end{array}$ & $4(3 ; 5)$ & $4(3 ; 5)$ & 0,695 \\
\hline 2. & $\begin{array}{l}\text { Те, що я роблю в терапії, дає мені нові способи розгляду } \\
\text { моєї проблеми }\end{array}$ & $4(3 ; 5)$ & $3,5(3 ; 5)$ & 0,716 \\
\hline 3. & Я вважаю, що я подобаюсь ФТ & $2,5(2 ; 4)$ & $3(2 ; 4)$ & 0,456 \\
\hline 4. & $\begin{array}{l}\text { ФТ і я співпрацюю над встановленням цілей для моєї } \\
\text { терапії }\end{array}$ & $4(3 ; 5)$ & $4(3 ; 5)$ & 0,493 \\
\hline 5. & ФТ і я поважаємо один одного & $5(4 ; 5)$ & $5(4 ; 5)$ & 0,712 \\
\hline 6. & ФТ і я працюємо у напрямку взаємно узгоджених цілей & $5(4 ; 5)$ & $5(4,25 ; 5)$ & 0,267 \\
\hline 7. & Я відчуваю, що ФТ цінує мене & $4,5(3 ; 5)$ & $4(3 ; 5)$ & 0,455 \\
\hline 8. & $\begin{array}{l}\text { ФТ і я згодні з тим, що для мене важливо працювати (над } \\
\text { собою) }\end{array}$ & $5(4 ; 5)$ & $5(4 ; 5)$ & 0,705 \\
\hline 9. & $\begin{array}{l}\text { Я відчуваю, що ФТ піклується про мене, навіть коли я } \\
\text { роблю те, що ФТ не схвалює }\end{array}$ & $4(3 ; 5)$ & $5(4 ; 5)$ & 0,072 \\
\hline 10. & $\begin{array}{l}\text { Я відчуваю, що те, що я роблю в терапії, допоможе мені } \\
\text { виконати ті зміни, які я хочу }\end{array}$ & $4(3,25 ; 5)$ & $4,5(3 ; 5)$ & 0,704 \\
\hline 11. & $\begin{array}{l}\text { ФТ і я встановили гарне розуміння тих змін, які були б } \\
\text { корисними для мене }\end{array}$ & $4(3,25 ; 5)$ & $5(4 ; 5)$ & 0,181 \\
\hline 12. & $\begin{array}{l}\text { Я вважаю, що спосіб роботи з моєю проблемою } \\
\text { правильний }\end{array}$ & $5(4 ; 5)$ & $5(4,25 ; 5)$ & 0,180 \\
\hline
\end{tabular}

Примітка: ФТ - фізичний терапевт.

пункті анкети. Порівняння результатів груп у доменах та загального балу терапевтичного альянсу не встановило достовірної різниці між групами (Табл. 2).

Частотний аналіз відповідей у першому пункті опитувальника для пацієнтів («У результаті цих сесій я більш чітко розумію, як я можу змінитися») виявив, що розподіл відповідей «рідко» / «іноді» / «досить часто» / «дуже часто» / «завжди» мав вигляд 6,8\% / 6, $8 \%$ / 25\% / 18,2\% / 43,2\% у КГ, а у IMT 2,3\% / 6,8\% / 20,5\% / 29,5\% / 40,9\% відсотків. Таким чином, у обох вибірках відповідь «завжди» отримала найбільшу частку.

Аналіз відповідей другого пункту опитувальника («Те, що я роблю в терапії, дає мені нові способи розгляду моєї проблеми») встановив, що розподіл аналогічних відповідей у КГ склав 4,5\% / 13,6\% / 22,7\% / 25\% / 34,1\%, а у групі IMT $0 \% / 20,5 \%$ / 29,5\% / 15,9\% / 34,1 \%. Відповідно, відповідь «завжди» у цьому пункті отримала дещо менший відсоток, але він був найвищим серед інших відповідей.
Співпраця у встановленні цілей (4 пункт опитувальника) також була досить високо та статистично однаково оцінена у вибірках пацієнтів, а розподіл відповідей у КГ та IMT становив відповідно 2,3\% / 13,6\% / 18,2\% / $27,3 \% / 38,6 \%$ та 4,5\% / 2,3\% / 25\% / 22,7\% / $45,5 \%$. Оцінка праці у напрямку взаємоузгоджених цілей (6 пункт опитувальника) статистично не відрізнялася у вибірках, незважаючи, що пацієнти групи IMT додатково співпрацювали 3 фізичними терапевтами при розучуванні роботи 3 дихальним тренажером та при наступному покращенні навички. Розподіл відповідей у КГ та ІМТ становив відповідно $0 \%$ / 2,3\% / 6,8\% / 31,8\% / 59,1\% та $0 \% / 6,8 \% / 9,1 \% / 9,1 \% / 75 \%$.

Порівняння результатів доменів також не встановило достовірних відмінностей між групами пацієнтів. Результати домену «ціль» склали $18(15 ; 19,75)$ балів у КГ та $19(15,25 ; 20)$ балів у IMT $(\mathrm{p}=0,259)$. У домені «завдання» статистичні показники КГ склали $17(14 ; 18)$ балів, а у IMT $16,5(14 ; 19)$ балів $(\mathrm{p}=0,680)$. 
Порівняння показників домену «взаємовідносини» не встановило преваг жодної з вибірок: КГ - $16(13,25 ; 18)$ балів, а IMT - $17(13,25 ; 18)$ балів ( $\mathrm{p}=0,681)$. Загальний показник у групах також не відрізнявся у КГ та IMT: $51(43,25$; $54,75)$ бал проти $52(42,25 ; 56)$ бала $(\mathrm{p}=0,437)$.

Обговорення. Розглянуті результати не підтвердили вплив від додаткової респіраторної ФТ у вигляді тренувань інспіраторних м'язів 3 дихальним тренажером Respironics Threshold IMT на показники терапевтичного альянсу між кардіохірургічними пацієнтами та їх фізичними терапевтами. Можна припустити, що рівень формування терапевтичного альянсу у рамках стандартної програми ФТ, досить важко покращити, якщо програма реалізується якісно і відповідно до зазначених ключових особливостей. Формування та досягнення специфічних цілей та завдань при роботі з дихальними тренажерами не покращило показники у жодному пункті та домені опитувальника, незважаючи на те, що дихальні вправи з тренажерами являються додатковою співпрацею пацієнта 3 фізичним терапевтом, котра реалізовувалася у формі пояснень особливостей і алгоритму роботи, контролю практичної реалізації дихальних вправ, контролю формування правильної навички, своєчасної корекції помилок для покращення техніки, мотивування та підвищення старанності пацієнта при виконанні дихальних вправ з тренажерами. Беручи до уваги отримані результати, можна зробити припущення, що формування та досягнення цілей та завдань при мобілізації пацієнта, при виконанні терапевтичних фізичних вправ, при інших аспектах ведення пацієнта (відкашлювання, консультації щодо рухової активності), а також співпраця впродовж відновлення функціональних можливостей $є$ ключовими факторами, котрі формують терапевтичний альянс між кардіохірургічним пацієнтом та фізичним терапевтом.

Проведений аналіз наукових досліджень виявив відсутність досліджень впливу додаткових інтервенцій, зокрема додаткової респіраторної ФТ,) на формування терапевтичного альянсу між кардіохірургічними пацієнтами та фізичними терапевтами. Автори переважної більшості попередніх наукових досліджень вивчали зв>язок між рівнем терапевтичного альянсу та результативністю ФТ, а також фактори, котрі впливають на виникнення та рівень терапевтичного альянсу між фізичним терапевтом та пацієнтом. Серед цих досліджень терапевтичного альянсу у сфері ФТ майже усі проводилися серед пацієнтів 3 порушеннями м'язово-скелетної системи.

Зокрема було встановлено, що терапевтичний альянс має зв язок з показниками болю, функціонування, загальним ефектом від лікування при ФТ пацієнтів 3 хронічним болем у попереку (Ferreira et al., 2013). Серед пацієнтів 3 м'язово-скелетними порушеннями, котрі проходили амбулаторний курс ФТ, встановлено вплив ставлення до хвороби на показники терапевтичного альянсу. Так, пацієнти 3 ірраціональним ставленням до хвороби мали достовірно нижчі результати у вісьмох пунктах опитувальника WAI порівняно з пацієнтами 3 раціональним ставленням до хвороби, а також мали нижчі результат у доменах «ціль», «завдання» та «взаємовідносини» (Fedorenko et al., 2019). Окрім того, у наукових роботах відзначають, що комунікаційним навичкам, котрі сприяють поліпшенню формуванню терапевтичного альянсу з пацієнтом, можна навчити (Lewin et al., 2001; Moore et al., 2004; McGilton et al., 2009). 3 іншої сторони, літературний огляд показав розбіжність щодо взаємозв язку терапевтичного альянсу та показниками болю у наукових дослідженнях, котрі не досліджувати чи не використовували заходи стимулювання/поліпшення терапевтичного альянсу (Taccolini Manzoni et al., 2018).

Інший літературний огляд виявив наявність прямопропорційних зв'язків між оцінками терапевтичного альянсу та критеріями ефективності ФТ серед осіб з порушеннями м'язово-скелетної системи (Hall et al., 2010). Наявні підтвердження впливу рівня терапевтичного альянсу на загальний бал оцінки ФТ, динаміку показників болю (Zaproudina et al., 2009), а також рівень задоволеності лікуванням (Beattie et al., 2005). Окрім того, повідомлялося, що серед пацієнтів з хронічним болем у шиї, котрі мали кращу динаміку впродовж програми ФТ, відзначалися кращі оцінки у здатності спілкуватися та взаємодіяти (Zaproudina et al., 200). 
Раніше повідомлялося, що пацієнти розглядають терапевтичний альянс 3 точки зору співпраці, зобов'язань, впевненого прогресу, взаємовідносин, згоди щодо завдань/цілей та продуктивної роботи (Bachelor, 2013). Проте проведене дослідження та отримані результати не підтвердили покращення показників терапевтичного альянсу за рахунок включення у програму ФТ додаткової респіраторної ФТ у формі роботи з дихальним тренажером. Це дає змогу стверджувати, що терапевтичний альянс формується під час виконання компонентів стандартної програми фізичної терапії для пацієнтів після кардіохірургічних втручань.

Висновки. Статистичний аналіз не встановив переваг жодної з груп у показниках терапевтичного альянсу. Додаткове визначення, узгодження та процес досягнення специфічних для роботи 3 дихальними тренажерами цілей та завдань не покращили результати навіть у доменах «ціль» та «завдання», незважаючи на те, що вправи з дихальними тренажерами були додатковою співпрацею між фізичними терапевтами та пацієнтами у одній 3 груп пацієнтів. Таким чином, встановлено відсутність впливу додаткової респіраторної ФТ у формі виконання інспіраторних м'язових тренувань 3 дихальним тренажером на показники пунктів та доменів опитувальника оцінки терапевтичного альянсу, а також на загальний бал.

Фінансування. Автор не отримав фінансової підтримки на дослідження, авторство та / або публікацію цієї статті.

\section{СПИСОК ЛІТЕРАТУРИ}

Babatunde, F., MacDermid, J., \& MacIntyre, N. (2017). Characteristics of therapeutic alliance in musculoskeletal physiotherapy and occupational therapy practice: a scoping review of the literature. BMC health services research, 17(1), 375. https://doi.org/10.1186/s12913-017-2311-3

Bachelor A. (2013). Clients and therapists $>$ views of the therapeutic alliance: similarities, differences and relationship to therapy outcome. Clinical psychology \& psychotherapy, 20(2), 118-135. https://doi.org/10.1002/cpp.792.

Balazh, M., Kormiltsev, V., Kostenko, V., Vitomskyi, V., Strohanov, S., Sabadosh, M., ... \& Martseniuk, I. (2020). Physical rehabilitation program of patients with ischemic heart disease with metabolic syndrome. Journal of Physical Education and Sport, 20 (6), 3528-3535. https://doi.org/10.7752/jpes.2020.06476

Beattie, P., Turner, C., Dowda, M., Michener, L., \& Nelson, R. (2005). The MedRisk Instrument for Measuring Patient Satisfaction With Physical Therapy Care: a psychometric analysis. The Journal of orthopaedic and sports physical therapy, 35(1), 24-32. https://doi.org/10.2519/jospt.2005.35.1.24

Fedorenko, S., Vitomskyi, V., Lazarieva, O., Kashuba, V., Andrieieva, O., Vitomska, M., ... \& Yurii, L. (2020). Influence Specificities of the Type of Attitude towards a Disease on Physical Therapy Satisfaction Among the Orthopedic Profile Patients and the Possibilities of Attitude Improvement. Journal of Physical Education and Sport, 20(2), 896-904.

Fedorenko, S., Vitomskyi, V., Lazarieva, O., \& Vitomska, M. (2019). The results of the analysis of the criteria of therapeutic alliance of patients orthopedic profile of outpatient physical therapy program. Health, sport, rehabilitation, 5(3), 13-23. http://dx.doi.org/10.34142/HSR.2019.05.03.02

Ferreira, P. H., Ferreira, M. L., Maher, C. G., Refshauge, K. M., Latimer, J., \& Adams, R. D. (2013). The therapeutic alliance between clinicians and patients predicts outcome in chronic low back pain. Physical therapy, 93(4), 470-478. https://doi.org/10.2522/ptj.20120137

Hall, A. M., Ferreira, P. H., Maher, C. G., Latimer, J., \& Ferreira, M. L. (2010). The influence of the therapist-patient relationship on treatment outcome in physical rehabilitation: a systematic review. Physical therapy, 90(8), 1099-1110. https://doi.org/10.2522/ptj.20090245

Hall, M. A., Zheng, B., Dugan, E., Camacho, F., Kidd, K. E., Mishra, A., \& Balkrishnan, R. (2002). Measuring patients trust in their primary care providers. Medical care research and review : MCRR, 59(3), 293-318. https://doi. org/10.1177/1077558702059003004

Horvath, A. O. (1994). Empirical validation of Bordin >s pantheoretical model of the alliance: The Working Alliance Inventory perspective. In A. O. Horvath \& L. S. Greenberg (Eds.), The working alliance: Theory, research, and practice (pp. 109-128). John Wiley \& Sons.

Kinney, M., Seider, J., Beaty, A. F., Coughlin, K., Dyal, M., \& Clewley, D. (2020). The impact of therapeutic alliance in physical therapy for chronic musculoskeletal pain: A systematic review of the literature. Physiotherapy theory and practice, 36(8), 886-898. https://doi.org/10.1080/09593985.2018.1516015 
Lawford, B. J., Bennell, K. L., Campbell, P. K., Kasza, J., \& Hinman, R. S. (2020). Therapeutic Alliance Between Physical Therapists and Patients With Knee Osteoarthritis Consulting Via Telephone: A Longitudinal Study. Arthritis care \& research, 72(5), 652-660. https://doi.org/10.1002/acr.23890

Lewin, S., Skea, Z., Entwistle, V. A., Zwarenstein, M., \& Dick, J. (2001). Interventions for providers to promote a patientcentred approach in clinical consultations. Cochrane database of systematic reviews, 4, 1-64. DOI: 10.1002/14651858. CD003267.

Martin, D. J., Garske, J. P., \& Davis, M. K. (2000). Relation of the therapeutic alliance with outcome and other variables: a meta-analytic review. Journal of consulting and clinical psychology, 68(3), 438-450.

McGilton, K. S., Boscart, V., Fox, M., Sidani, S., Rochon, E., \& Sorin-Peters, R. (2009). A systematic review of the effectiveness of communication interventions for health care providers caring for patients in residential care settings. Worldviews on evidence-based nursing, 6(3), 149-159. https://doi.org/10.1111/j.1741-6787.2009.00155.x

Mercer, S. W., Maxwell, M., Heaney, D., \& Watt, G. C. (2004). The consultation and relational empathy (CARE) measure: development and preliminary validation and reliability of an empathy-based consultation process measure. Family practice, 21(6), 699-705. https://doi.org/10.1093/fampra/cmh621

Moore, P. M., Rivera Mercado, S., Grez Artigues, M., \& Lawrie, T. A. (2013). Communication skills training for healthcare professionals working with people who have cancer. The Cochrane database of systematic reviews, 2013(3), CD003751. https://doi.org/10.1002/14651858.CD003751.pub3

Munder, T., Wilmers, F., Leonhart, R., Linster, H. W., \& Barth, J. (2010). Working Alliance Inventory-Short Revised (WAI-SR): psychometric properties in outpatients and inpatients. Clinical psychology \& psychotherapy, 17(3), $231-239$. https://doi.org/10.1002/cpp.658.

Robert L. Hatcher \& J. Arthur Gillaspy (2006) Development and validation of a revised short version of the working alliance inventory, Psychotherapy Research, 16:1, 12-25, DOI: 10.1080/10503300500352500

Taccolini Manzoni, A. C., Bastos de Oliveira, N. T., Nunes Cabral, C. M., \& Aquaroni Ricci, N. (2018). The role of the therapeutic alliance on pain relief in musculoskeletal rehabilitation: A systematic review. Physiotherapy theory and practice, 34(12), 901-915. https://doi.org/10.1080/09593985.2018.1431343

Vitomskiy, V., Hruzevych, I., Salnykova, S., Sulyma, A., Kormiltsev, V., Kyrychenko, Y., \& Sarafinjuk, L. (2018). The physical development of children who have a functionally single heart ventricle as a basis for working physical rehabilitation technology after a hemodynamic correction. Journal of Physical Education and Sport, 18(2), 614-617.

Vitomskyi, V. (2020). The impact of mobilization and other factors on pleural effusion in patients undergoing cardiac surgical procedures. Journal of Physical Education and Sport, 20 (Supplement issue 3), 2167-2173.

Zaproudina, N., Hänninen, O. O., \& Airaksinen, O. (2007). Effectiveness of traditional bone setting in chronic neck pain: randomized clinical trial. Journal of manipulative and physiological therapeutics, 30(6), 432-437. https://doi. org/10.1016/j.jmpt.2007.05.004

Zaproudina, N., Hietikko, T., Hänninen, O. O., \& Airaksinen, O. (2009). Effectiveness of traditional bone setting in treating chronic low back pain: a randomised pilot trial. Complementary therapies in medicine, 17(1), 23-28. https://doi. org/10.1016/j.ctim.2008.08.005 


\section{ВЛИЯНИЕ ИНСПИРАТОРНЫХ МЫШЕЧНЫХ ТРЕНИРОВОК \\ НА ПОКАЗАТЕЛИ \\ ТЕРАПЕВТИЧЕСКОГО АЛЬЯНСА \\ В РАМКАХ ПРОГРАММЫ \\ ФИЗИЧЕСКОЙ ТЕРАПИИ \\ КАРДИОХИРУРГИЧЕСКОГО \\ ПАЦИЕНТОВ}

\section{Витомский Владимир}

Преподаватель, Национальный

университет физического воспитания и спорта Украины, Украина

Аннотация. Цель оценить влияние включения тренировок инспираторных мышц на формирование терапевтического альянса в рамках стационарной программы физической терапии после кардиохирургических вмешательств. В опросе приняли участие 88 пациентов, которым проводилось кардиохирургическое вмешательство с стернотомией и искусственным кровообращением. Пациентов случайным образом распределили в соотношении $1: 1$ в контрольную группу (КГ, $\mathrm{n}=44)$ и группу тренировок инспираторных мышц (ИМТ, $\mathrm{n}=44)$. Со всеми пациентами перед операцией проводилась короткая консультация физического терапевта относительно целей и содержания программы физической терапии, алгоритма активизации после операции. Послеоперационный протокол физической терапии предусматривал раннюю мобилизацию, лечебную гимнастику. После операции респираторная физическая терапия в КГ ограничивалась кашлем, а в группе ИМТ дополнительно использовался дыхательный тренажер Respironics Threshold IMT и соответственно обучение пациентов касательно особенностях его использования. Таким образом, для пациентов группы ИМТ было характерно дополнительное формирование и достижение специфических целей и задач при работе с дыхательными тренажерами, дополнительное сотрудничество пациента с физическим терапевтом, которое реализовывалось в форме объяснений особенностей и алгоритма работы, контроля практической реализации

\section{THE INFLUENCE OF INSPIRATORY MUSCLE TRAINING ON INDICATORS OF THERAPEUTIC ALLIANCE DURING PHYSICAL THERAPY PROGRAM OF CARDIOSURGERY PATIENTS}

\author{
Vitomskyi Volodymyr \\ Lecturer, National University of Ukraine on \\ Physical Education and Sport, Ukraine
}

Abstract. The aim of the work was to evaluate the impact of the inclusion of inspiratory muscle training on the formation of a therapeutic alliance within the inpatient physical therapy program after cardiac surgery. The survey involved 88 patients who underwent cardiac surgery with sternotomy and artificial circulation. Patients were randomly assigned in a 1:1 ratio to the control group (CG, $n=44)$ and the inspiratory muscle training group (IMT, $n=44$ ). All patients before the operation were briefly consulted by a physical therapist about the goals and content of the physical therapy program, the algorithm of activation after surgery. The postoperative protocol of physical therapy provided for early mobilization, therapeutic gymnastics. After the operation, respiratory physical therapy in CG was limited to cough, and in the IMT group, the Respironics Threshold IMT breathing exerciser was additionally used and, accordingly, patients were educated on the peculiarities of its use. Thus, IMT patients were characterized by additional formation and achievement of specific goals and objectives when working with breathing exerciser, additional cooperation of the patient with a physical therapist, which was implemented in the form of explanations of the features and algorithm, control of practical implementation of breathing exercises, timely correction of errors to improve technique, motivation and diligence of the patient when performing breathing exercises with exerciser. In order to assess the level of formation of the therapeutic alliance, Working Alliance Inventory questionnaire was used. The comparison of the results of the groups by questionnaire items did not establish significant differences between the samples in any of the questionnaire items. Comparison of the results of the domains also did not establish significant differences between 
дыхательных упражнений, контроля формирования правильного навыка, своевременной коррекции ошибок для улучшения техники, мотивирование и повышение исполнительности пациента при выполнении дыхательных упражнений с тренажерами. С целью оценки уровня формирования терапевтического альянса применялся опросник Оценка рабочего альянса. Сравнение результатов групп по пунктам опросника не установило достоверных различий между выборками ни в одном пункте анкеты. Сравнение результатов доменов также не установило достоверных различий между группами пациентов. Результаты домена «цель» составили $18(15 ; 19,75)$ баллов в КГ и $19(15,25,20)$ баллов в ИМТ $(\mathrm{p}=0,259)$. В домене «задачи» статистические показатели КГ составили $17(14,18)$ баллов, а в ИМТ $16,5(14 ; 19)$ баллов $(\mathrm{p}=0,680)$. Сравнение показателей домена «взаимоотношения» не установило преимуществ у одной из выборок КГ $16(13,25,18)$ баллов, а ИМТ $17(13,25$; $18)$ баллов $(\mathrm{p}=0,681)$. Общий показатель в группах также не отличался в КГ и ИМТ: 51 $(43,25 ; 54,75)$ балл против $52(42,25 ; 56)$ балла $(\mathrm{p}=0,437)$. Дополнительное определение, согласование и процесс достижения специфических для работы с дыхательными тренажерами целей и задач не улучшили результаты терапевтического альянса несмотря на то, что упражнения с дыхательными тренажерами были дополнительным сотрудничеством между физическими терапевтами и пациентами в группе тренировок инспираторных мышц.

Ключевые слова: кардиореабилитации, рабочий союз, терапевтические упражнения, физическая терапия, дыхательные упражнения. groups of patients. The results of the domain «goal items «were $18(15 ; 19.75)$ points in CG and $19(15.25 ; 20)$ points in IMT $(p=0.259)$. In the «task items « domain, the CG statistics were $17(14 ; 18)$ points, and in the IMT $16.5(14 ; 19)$ points $(p=0.680)$. Comparison of the indicators of the domain «bond items» did not establish the advantages of any of the samples: CG $16(13,25$; 18) points, and IMT - $17(13,25 ; 18)$ points $(p=0,681)$. The overall score in the groups also did not differ in CG and IMT: $51(43.25 ; 54.75)$ points against $52(42.25 ; 56)$ points $(\mathrm{p}=0.437)$. The additional definition, coordination and process of achieving specific goals and objectives for working with respiratory simulators did not improve the results of the therapeutic alliance, despite the fact that exercises with respiratory simulators were additional cooperation between physical therapists and patients in the inspiratory muscle training group.

Key words: cardiorehabilitation, working union, therapeutic exercises, physical therapy, breathing exercises. 